\title{
Patterns of Mobilization of the Proteus mirabilis Chromosome by R Plasmids
}

\author{
By J. N. COETZEE \\ Department of Microbiology, University of Pretoria, Republic of South Africa
}

(Received 4 September 1978)

\begin{abstract}
R plasmids R40a, Rip69, R447b, R769 belonging to incompatibility groups A-C, M, N, V, respectively, were investigated for chromosomal mobilizing ability in Proteus mirabilis. Plasmids R40a, Rip69 and R447b mediated polarized transfer of markers in a clockwise direction from origins near $t y r-1$, met $F$ and ser-2, respectively, on the linkage map. The recovery frequency per donor cell of proximal markers approached $1 \times 10^{-4}$ for these three plasmids and the efficiency of chromosomal transfer was higher than that of the previously studied plasmid D. The plasmid-guided chromosomal trajectories overlap and it was possible to complement results obtained with plasmid D to assemble a time-of-entry chromosomal map and directly establish the circularity of the linkage group. The map comprises a length of $93 \mathrm{~min}$ in terms of transfer time. Plasmid R769 had a different pattern of chromosome transfer. This plasmid produced recombinants for all markers at frequencies of about $4 \times 10^{-6}$ per donor. It effected multiple and more or less simultaneous entry of markers and produced recombination over lengths of chromosome rarely corresponding to more than $10 \mathrm{~min}$ on the linkage map.
\end{abstract}

\section{INTRODUCTION}

During a conjugation event $\mathbf{R}$ plasmids may mobilize the bacterial chromosome from one particular site. This results in a decreasing frequency of marker recovery distal to the site. Such a polarized transfer of markers has been recorded for Escherichia coli (Pearce \& Meynell, 1968; Moody \& Runge, 1972; Hedén \& Rutberg, 1976), Salmonella typhimurium (Hedén \& Meynell, 1976), Klebsiella pneumoniae (Dixon et al., 1975), Pseudomonas aeruginosa (Stanisich \& Holloway, 1971; Watson \& Holloway, 1978), Acinetobacter calcoaceticus (Towner \& Vivian, 1976 $a, b$ ) and for chromosome mobilization of $P$. mirabilis by a hybrid $\mathrm{R}$ plasmid (Coetzee, 1975, 1978a).

Mobilization by $\mathbf{R}$ plasmids may also proceed (more or less simultaneously) from a number of chromosomal sites during conjugation. The polarized transfer of one particular event is then scrambled in the population as a whole with the result that the frequency of transfer of chromosomal markers may be similar. This has been recorded for E. coli (Sugino \& Hirota, 1962; Cooke \& Meynell, 1969), Pseudomonas aeruginosa (Haas \& Holloway, 1976), Rhizobium leguminosarum (Beringer \& Hopwood, 1976), R. meliloti (Meade \& Signer, 1977; Kondorosi et al., 1977) and P. mirabilis (Coetzee, 1978b, 1979). A similar pattern of chromosome mobilization in E. coli and S. typhimurium is produced by colicin I plasmids (Ozeki et al., 1961). This paper reports on the way in which four newly investigated $\mathrm{R}$ plasmids mobilize the $P$. mirabilis strain PM5006 chromosome.

\section{METHODS}

Bacteria and plasmids. These are listed in Table 1.

Media. Media were as described previously (Coetzee, 1978b).

Antibacterial drugs. Nalidixic acid, ampicillin, kanamycin, streptomycin, tetracycline or polymixin B (each 0022-1287/79/0000-8353 \$02.00 (C) 1979 SGM

Vol. 111, No. 1 was issued 14 March 1979 


\begin{tabular}{|c|c|c|c|}
\hline Bacteria & Genotype & Derivation & Reference \\
\hline \multicolumn{4}{|c|}{ Proteus mirabilis } \\
\hline PM5006 & $\begin{array}{l}\text { Wild-type strain resistant to PMX } \\
\text { and } \mathrm{T} \ddagger\end{array}$ & - & Coetzee \& Smit (1970) \\
\hline UP3 & his-1 nalAl & PM5006 nalAl & Coetzee (1975) \\
\hline UP4 & pyrBI nalAI & PM5006 nalA1 & Coetzee (1975) \\
\hline UP7 & tyr-1 str-1 & PM5006 str-1 & Coetzee (1975) \\
\hline UP19 & ura-3 ser-2 his-1 nalA1 str-2 & UP18 & Coetzee (1975) \\
\hline UP21 & trp-3 his-1 nalA1 str-2 & UP16 & Coetzee (1975) \\
\hline UP47 & leuB2 pyrB1 nalA1 & UP4 & Coetzee $(1978 a)$ \\
\hline UP49 & argEI pyrBI nalAl & UP4 & Coetzee $(1978 a)$ \\
\hline UP77 & $\operatorname{argE2}$ tyr-1 str-1 & UP7 & Coetzee $(1975,1978 a)$ \\
\hline UP177 & $\begin{array}{l}\text { cysA12 gly-17 } \operatorname{argA7} \text { pyrB2 his-1 } \\
\text { nalA1 str-2 (gly-17 presumed } \\
\text { allelic with } g l y-1)\end{array}$ & UP17 & Coetzee $(1975,1978 b, 1979)$ \\
\hline UP433 & cysCI nalA1 & UP43 & Coetzee $(1978 a)$ \\
\hline UP476 & metF6 leuB2 nalAl & UP477 & Coetzee $(1978 b)$ \\
\hline UP477 & leuB2 nalA1 & UP47 & Coetzee $(1978 a)$ \\
\hline UP500 & pyrBI rif-1 nalA1 & UP4 & Coetzee $(1978 b)$ \\
\hline UP600 & $\begin{array}{l}\text { argE7 met-201 tyr-2 pyrB1 nalA1 } \\
\text { (met-201 presumed allelic with } \\
\text { met-107; tyr-2 presumed allelic } \\
\text { with tyr-1) }\end{array}$ & UP48 & Coetzee $(1978 a, 1979)$ \\
\hline UP1111 & cys $A 4 \operatorname{trp}-1$ & UP1 & Coetzee $(1975,1979)$ \\
\hline UP5023 & $\begin{array}{l}\text { thr-4 metF10 arg } A 4 \text { lys-98 leuB4 } \\
\text { tyr-2 pyrB1 nalAI (thr-4 presumed } \\
\text { allelic with } \text { thr- } 1^{*} ; \text { metF10 } \\
\text { presumed allelic with metF2 } \\
\text { metF } 4 \text { metF } 6^{*} ; \text { arg } A 4 \text { presumed } \\
\left.\text { allelic with } \arg A 2^{*}\right)\end{array}$ & UP502† & Coetzee (1979, and unpublished) \\
\hline UP6011 & $\begin{array}{l}\text { ser-6 met-107 argE3 his-1 nalA1 } \\
(\text { ser-6 presumed allelic with } \\
\left.\text { ser }-2^{*}\right)\end{array}$ & UP601† & Coetzee (1979, and unpublished) \\
\hline UP44442 & $\begin{array}{l}\text { ilv-13 ade- } 4 \text { metF } 4 \text { cysC3 } \text { arg } A 2 \\
\text { nalA1 (ilv-13 presumed allelic } \\
\text { with ilv-2*; ade-4 presumed } \\
\text { allelic with ade-2*) }\end{array}$ & UP4444† & Coetzee (1979, and unpublished) \\
\hline \multicolumn{4}{|c|}{ Escherichia coli } \\
\hline $\mathrm{J} 53-2$ & pro met rif- $1, \mathrm{~F}^{-}$ & E. coli $\mathrm{K} 12$ & $\begin{array}{l}\text { Clowes \& Hayes (1968); } \\
\text { R. W. Hedges }\end{array}$ \\
\hline Plasmids & \multicolumn{2}{|l|}{ Relevant properties } & Reference \\
\hline R40a & \multicolumn{2}{|c|}{ Incompatibility group A-C; A, K, Su $\ddagger$} & $\begin{array}{l}\text { R. W. Hedges; Datta \& Hedges } \\
\text { (1972) }\end{array}$ \\
\hline Rip69 & \multicolumn{2}{|c|}{ Incompatibility groun $\mathbf{M} ; \mathbf{A}, \mathbf{T}, \mathbf{K} \ddagger$} & R. W. Hedges \\
\hline R447b & \multicolumn{2}{|c|}{ Incompatibility group $\mathrm{N} ; \mathrm{A}, \mathrm{K} \ddagger$} & Hedges et al. (1973) \\
\hline R769 & \multicolumn{2}{|c|}{ Incompatibility group V; S, C, K, Su $\ddagger$} & Hedges (1975) \\
\hline
\end{tabular}

Table 1. Bacteria and plasmids

* The mutant strain was transduced (Coetzee et al., 1973) with phage 5006M propagated on the other mutant as well as on wild-type PM5006. Failure to produce prototrophic transductants at normal frequencies with phage reared on the mutant was taken as evidence for presumed allelism.

$\dagger N$-Methyl- $N^{\prime}$-nitro- $N$-nitrosoguanidine-induced mutations (unpublished) in strains previously used (Coetzee, 1979).

† Symbols designate resistance to: A, ampicillin; C, chloramphenicol; K, kanamycin; PMX, polymixin; $\mathrm{S}$, streptomycin; Su, sulphonamide; $\mathrm{T}$, tetracycline.

$50 \mu \mathrm{g} \mathrm{ml}^{-1}$ ) were added to media when necessary. Streptomycin was also used at $1 \mathrm{mg} \mathrm{ml}^{-1}$ and rifampicin was used at $200 \mu \mathrm{g} \mathrm{ml}^{-1}$.

Plate matings. These were done by the method of Coetzee $(1978 a)$. Briefly, mating mixtures were constituted on non-selective minimal medium (i.e. supplemented with the growth requirements of the recipient and donor) and incubated at $30^{\circ} \mathrm{C}$ overnight before harvesting in saline. Control experiments lacked either donor or recipient. After washing, suitable dilutions were plated on selective media and incubated at the same temperature for $48 \mathrm{~h}$. 
Interrupted mating. This was done according to the solid medium nalidixic acid technique of Haas \& Holloway (1976), as previously used (Coetzee, 1978a).

Unselected marker analysis and recombinant stability. This was done according to the method of Coetzee (1978a).

Presence of $R$ plasmids in recombinants. For plasmids $\mathrm{R} 40 \mathrm{a}, \mathrm{Rip} 69$ and $\mathrm{R} 447 \mathrm{~b}$, this was tested by replication of patched recombinant colonies on the isolation minimal medium to the same medium containing ampicillin and kanamycin; the presence of R769 was tested by replication to plates containing kanamycin and also streptomycin where appropriate. Ability to transfer kanamycin resistance to UP500 was tested by the plate mating technique mentioned above, using rifampicin for donor counterselection on MacConkey agar also containing kanamycin.

Construction of $P$. mirabilis UP strains containing plasmids. The plate mating technique mentioned above was used. For transfer of plasmids from strains of $E$. coli, the donor was counterselected with polymixin or tetracycline where appropriate. Transfer of plasmids from wild-type Proteus strains to UP strains was achieved by first mating with J53-2, using rifampicin to counterselect the donor, and then with the UP strain as above. During plasmid transfer from UP strains to PM5006, the donor was counterselected by plating on minimal medium.

\section{RESULTS}

\section{Transfer of plasmids from UP strains to PM5006}

UP1111 strains each harbouring one of the four plasmids were mated individually with PM5006 using the technique described in Methods. Transfer frequencies per donor cell for R40a, Rip69, R447b and R769 were $8 \times 10^{-3}, 4 \times 10^{-3}, 4 \times 10^{-3}$ and $4 \times 10^{-2}$, respectively. The frequencies for plasmids R40a and R $447 \mathrm{~b}$ are about fourfold higher than those recorded for similar matings in broth (Datta \& Hedges, 1972; Coetzee, 1974). Meade \& Signer (1977) found a thousandfold difference in the frequency of transfer of plasmid RP4 between strains of $R$. meliloti in broth and on agar.

\section{Inheritance of chromosomal markers}

Transfer. Plasmid R769 produced similar recombinant recovery frequencies (about $4 \times 10^{-6}$ per donor cell) for markers distributed over the entire chromosome (Table 2 ). This suggested that there was no orientated gene transfer but that the plasmid directed chromosomal transfer from a number of different sites. All of many recombinants tested were resistant to kanamycin and, when acquisition of streptomycin resistance could be tested, these recombinants were also resistant to it. All those tested could also transmit kanamycin resistance to UP500 (not shown). Recovery frequencies of recombinants produced under promotion of each of the other three plasmids varied greatly for the different selected loci (Table 2). This suggested that polarity of marker entry could be occurring with clockwise mobilization of the chromosome from origins near his-1, metF and tyr-1 (Fig. 2) by plasmids R447b, Rip69 and R40a, respectively. All progeny were stable and behaved like haploid recombinants (Meade \& Signer, 1977). All of hundreds of recombinants tested were resistant to ampicillin and kanamycin. Many of them were tested for ability to transfer kanamycin resistance to UP500; all possessed this property (not shown).

Interrupted mating. A recovery frequency of at least $1 \times 10^{-5}$ per donor for certain chromosome markers (Table 2) made interrupted mating experiments feasible. As predicted from the results for marker transfer (Table 2), interrupted mating experiments using plasmid R769 in strain UP77 as chromosomal donor with UP177 as recipient showed that all markers tested $\left(c y s A^{+}, g l y-17^{+}, \arg A^{+}, p y r B^{+}, h i s-1^{+}\right)$registered in the recipient between 4 and 7 min after mating commenced (not shown). Similar mating experiments with the other three plasmids revealed that markers entered recipients sequentially from different origins in a definite temporal order (Fig. 1). The order corresponded exactly to that previously derived from linkage studies (Coetzee, 1979). When overlaps occurred, the time intervals between entry of some markers promoted by the different plasmids (ser-6-his-1, Figs 1 b, 2; cysCilv-13-ade-4, Figs 1 $c, 2$ ) corresponded closely with those recorded for plasmid D (Coetzee, 
Table 2. Recombination frequencies of markers using various plasmids as donors

Plate matings were done as described in Methods. Selective minimal medium was supplemented, when necessary, with the growth requirements for unselected recipient markers.

\begin{tabular}{|c|c|c|c|c|}
\hline Selected marker & $\begin{array}{c}\text { Map } \\
\text { location } \\
\text { (min) }\end{array}$ & Plasmid & $\begin{array}{l}\text { Recombination } \\
\text { frequency* }\end{array}$ & Cross \\
\hline$h i s-1^{+}$ & 7 & $\begin{array}{l}\text { R40a } \\
\text { R447b } \\
\text { Rip69 } \\
\text { R769 }\end{array}$ & $\begin{array}{r}<7 \times 10^{-9} \\
8 \times 10^{-5} \\
<7 \times 10^{-9} \\
5 \times 10^{-6}\end{array}$ & $\begin{array}{l}\text { UP19 } \times \text { UP477(R40a) } \\
\text { UP19 } \times \text { UP477(R447b) } \\
\text { UP19 × UP477(Rip69) } \\
\text { UP19 } \times \text { UP477(R769) }\end{array}$ \\
\hline pyrB $1^{+}$ & 18 & $\begin{array}{l}\text { R40a } \\
\text { R447b } \\
\text { Rip69 } \\
\text { R769 }\end{array}$ & $\begin{aligned}< & 5 \times 10^{-9} \\
< & 5 \times 10^{-9} \\
& 1 \times 10^{-8} \\
& 9 \times 10^{-6}\end{aligned}$ & $\begin{array}{l}\text { UP4 } \times \text { UP3(R40a) } \\
\text { UP4 } \times \text { UP3(R447b) } \\
\text { UP4 } \times \text { UP3(Rip69) } \\
\text { UP4 } \times \text { UP3(R769) }\end{array}$ \\
\hline cysCl+ & 42 & $\begin{array}{l}\text { R40a } \\
\text { R447b } \\
\text { Rip69 } \\
\text { R769 }\end{array}$ & $\begin{array}{r}9 \times 10^{-7} \\
<5 \times 10^{-9} \\
1 \times 10^{-5} \\
2 \times 10^{-6}\end{array}$ & $\begin{array}{l}\text { UP433 } \times \text { UP3(R40a) } \\
\text { UP433 } \times \text { UP3(R447b) } \\
\text { UP433 } \times \text { UP3(Rip69) } \\
\text { UP433 } \times \text { UP3(R769) }\end{array}$ \\
\hline metF $\sigma^{+}$ & 55 & $\begin{array}{l}\text { R40a } \\
\text { R447b } \\
\text { Rip69 } \\
\text { R769 }\end{array}$ & $\begin{array}{r}1 \times 10^{-8} \\
<5 \times 10^{-9} \\
1 \times 10^{-4} \\
2 \times 10^{-6}\end{array}$ & $\begin{array}{l}\text { UP476 × UP21(R40a) } \\
\text { UP476 × UP21(R447b) } \\
\text { UP476 × UP21(Rip69) } \\
\text { UP476 × UP21(R769) }\end{array}$ \\
\hline leuB2+ & 69 & $\begin{array}{l}\text { R40a } \\
\text { R447b } \\
\text { Rip69 } \\
\text { R769 }\end{array}$ & $\begin{array}{r}2 \times 10^{-5} \\
1 \times 10^{-8} \\
<7 \times 10^{-9} \\
3 \times 10^{-6}\end{array}$ & $\begin{array}{l}\text { UP47 } \times \text { UP21(R40a) } \\
\text { UP4 } \times \text { UP21(R447b) } \\
\text { UP47 } \times \text { UP21(Rip69) } \\
\text { UP47 × UP21(R769) }\end{array}$ \\
\hline tyr-1+ & 76 & $\begin{array}{l}\text { R40a } \\
\text { R447b } \\
\text { Rip69 } \\
\text { R769 }\end{array}$ & $\begin{array}{r}9 \times 10^{-5} \\
8 \times 10^{-7} \\
<5 \times 10^{-9} \\
6 \times 10^{-6}\end{array}$ & $\begin{array}{l}\text { UP7 } \times \text { UP21(R40a) } \\
\text { UP7 } \times \text { UP21(R447b) } \\
\text { UP7 } \times \text { UP21(Rip69) } \\
\text { UP7 } \times \text { UP21(R769) }\end{array}$ \\
\hline $\arg E 1^{+}$ & 85 & $\begin{array}{l}\text { R40a } \\
\text { R447b } \\
\text { Rip69 } \\
\text { R769 }\end{array}$ & $\begin{aligned}< & 5 \times 10^{-9} \\
& 4 \times 10^{-6} \\
< & 5 \times 10^{-8} \\
& 2 \times 10^{-6}\end{aligned}$ & $\begin{array}{l}\text { UP49 } \times \text { UP1111(R40a) } \\
\text { UP49 } \times \text { UP1111(R477b) } \\
\text { UP49 } \times \text { UP1111(Rip69) } \\
\text { UP49 } \times \text { UP1111(R769) }\end{array}$ \\
\hline
\end{tabular}

* Recovery of recombinants per donor cell in mating mixture.

Table 3. Segregation of unselected markers in crosses with plasmid R769 as donor

Plate matings were done as described in Methods. Selective minimal medium was supplemented with the growth requirements for unselected recipient markers. The crosses were UP44442 $\times$ UP4(R769) and UP5023 $\times$ UP3(R769).

\begin{tabular}{|c|c|c|c|c|c|c|c|c|c|}
\hline \multirow{2}{*}{$\begin{array}{c}\text { Selected } \\
\text { marker }\end{array}$} & \multicolumn{9}{|c|}{ Co-inheritance of unselected chromosomal markers $(\%)$} \\
\hline & $a d e^{+}$ & $i l v^{+}$ & cys $^{+}$ & $\arg ^{+}$ & $m e t^{+}$ & $t y r^{+}$ & $l y s^{+}$ & $\operatorname{leu}^{+}$ & $t h r^{+}$ \\
\hline ade- $4^{+}$ & - & 94 & 7 & 0 & 0 & 0 & 0 & 0 & 0 \\
\hline$i l v-13^{+}$ & 86 & - & 76 & 0 & 0 & 0 & 0 & 0 & 0 \\
\hline $\operatorname{cys} 3^{+}$ & 7 & 70 & - & 73 & 4 & 0 & 0 & 0 & 0 \\
\hline $\arg A 2^{+}$ & 0 & 0 & 73 & 一 & 92 & 0 & 0 & 0 & 4 \\
\hline metF4t & 0 & 0 & 2 & 86 & - & 0 & 0 & 0 & 66 \\
\hline$t y r-2^{+}$ & 0 & 0 & 0 & 0 & 0 & - & 82 & 76 & 14 \\
\hline lys $-98^{+}$ & 0 & 0 & 0 & 0 & 0 & 91 & - & 96 & 76 \\
\hline $\operatorname{leuB4^{+}}$ & 0 & 0 & 0 & 0 & 0 & 85 & 93 & - & 78 \\
\hline$t h r-4^{+}$ & 0 & 0 & 0 & 0 & 3 & 68 & 83 & 94 & - \\
\hline
\end{tabular}

* 150 recombinants for each selected marker were tested for the presence of unselected markers by the procedure described in Methods. 


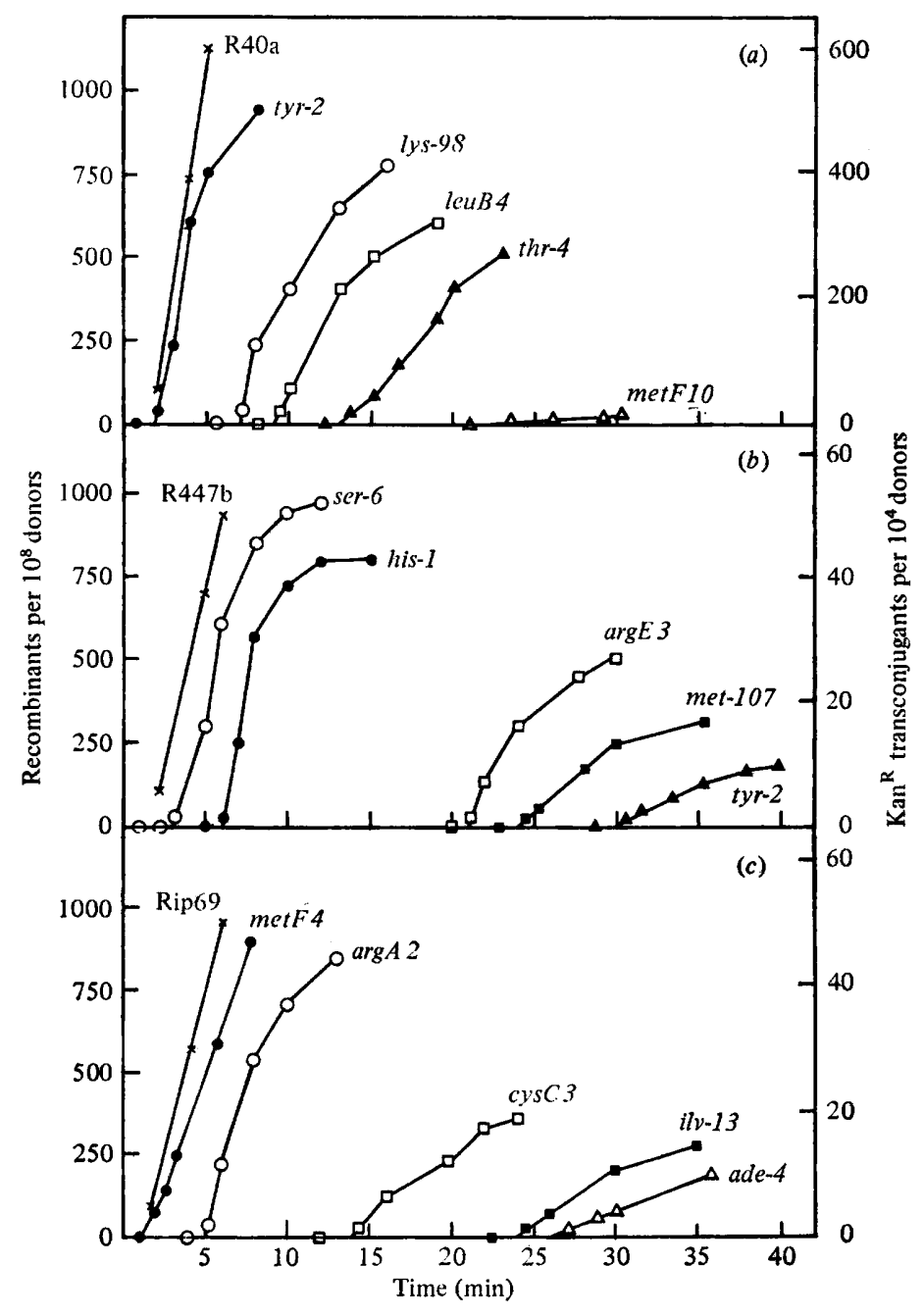

Fig. 1. Time of entry of donor markers. Interrupted plate matings were done as indicated in Methods. Mating was interrupted at intervals by spreading plates of the mating mixture (on selective minimal medium for the marker concerned) with a nalidixic acid solution to mix the bacterial growth thoroughly. Plates were then dried and incubated for $72 \mathrm{~h}$. Media were supplemented with the growth requirements of the unselected markers. To detect plasmid transfer, the media contained kanamycin (Kan) in addition to all the growth requirements of the particular recipient strain. Results are those of duplicate experiments. (a) UP5023 $\times$ UP1111(R40a). (b) UP6011 × UP7(R447b); UP600 × UP1111(R447b). (c) UP44442 × UP77(Rip69).

$1978 a, b, 1979)$. The gradients of entry of late markers are considerably reduced relative to those of early markers in all three experiments (especially that in Fig. $1 a$, see Discussion) and no attempt was made to select for more distal markers. The entry curves for kanamycin resistance (Fig. 1) show that, with all three plasmids, conjugation begins within 2 min after mixing of parent cultures as a measure of plasmid transfer.

Segregation of unselected markers. Knowledge of the time intervals between entry of sets of proximal markers gained from the above experiments enabled an estimate (see Coetzee, $1978 a, b)$ of the extent over which plasmid R769-mediated chromosome recombination took place. In crosses UP44442 $\times$ UP4(R769) and UP5023 $\times$ UP3(R769), sets of linkage data were obtained (Table 3 ). The results are consistent with there being only one chromosomal transfer event per recombinant and with the marker order derived from the interrupted 


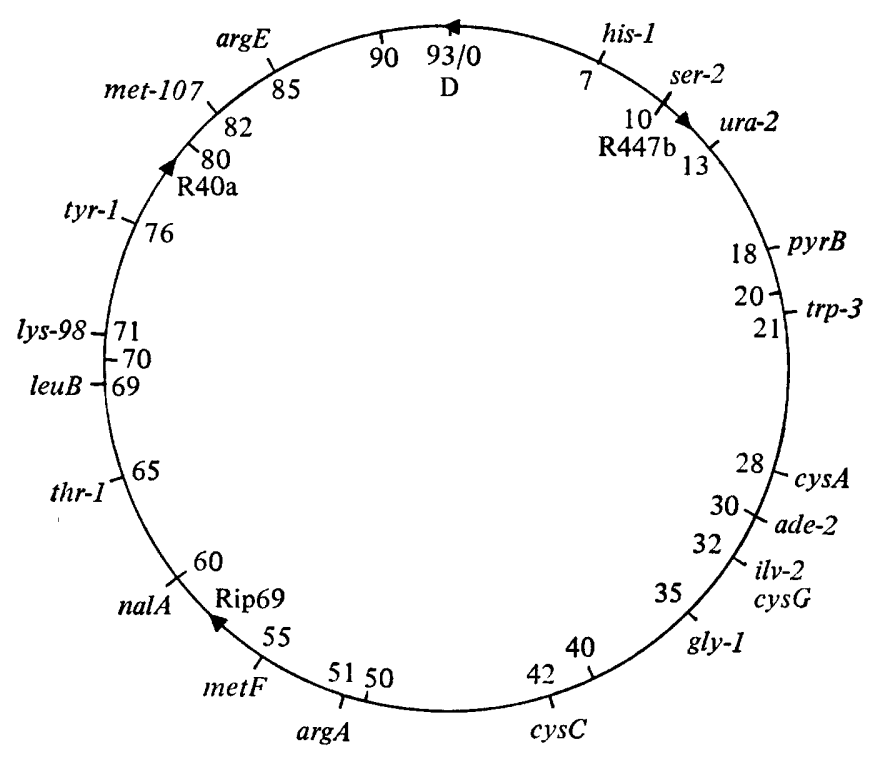

Fig. 2. Revised chromosome map (Coetzee, 1979) of $P$. mirabilis strain PM5006. This map is a composite arrangement, to scale, of plasmid D, R40a, Rip69 and R447b-mediated chromosome loci, with entrance times in minutes. As before (Coetzee, 1979), the transfer origin of plasmid D is designated as $0 \mathrm{~min}$. The time interval between locus $\arg E$ and the origin of plasmid $\mathrm{D}$ is calculated as the difference in the interval between plasmid R447b-mediated entry of markers argE 3 and his-1 (Fig. $1 b$ ) and the time of entry of his- $I$ under promotion of plasmid D (Coetzee, 1978 b, 1979). The plasmid $D$ trajectory remains intact apart from the $i l v-2$ marker which is now spaced 2 min clockwise from ade-2. The cysG locus is situated very near $i l v-2$ but the time-of-entry relationship to the latter marker has not been investigated. The time interval between loci $t h r-1$ and nalA is not known and the interval between the $t h r-1$ and $m e t F$ is approximate. Arrowheads indicate the approximate origin and direction of chromosome transfer by the plasmids.

mating experiments. It is evident that recombinants seldom inherit a length of donor chromosome corresponding to longer than $10 \mathrm{~min}$ on the transfer map (Fig. 2).

\section{Revised circular linkage group}

It was now possible to use the interrupted mating results obtained above and previously (Coetzee, 1975, 1978a) to assemble a marker time of entry map comprising a total length of $93 \mathrm{~min}$ in terms of transfer time (Fig. 2). The derivation of this map is based on the assumption that the rates of chromosomal mobilization by plasmid $\mathrm{D}$ (Coetzee, 1975, 1978a) and the three plasmids studied here are similar. Watson \& Holloway (1978) have made similar assumptions about the rates at which different plasmids mobilize the Pseudomonas aeruginosa chromosome.

\section{DISCUSSION}

Apart from plasmid D (Coetzee, 1978 b), which is a fusion product of plasmids P-lac and R1drd19 belonging to incompatibility groups A-C (Hedges, 1975) and FII (Meynell \& Datta, 1966, 1967; Meynell \& Cooke, 1969; Hedges \& Datta, 1972), respectively, six other plasmids have now proved capable of mobilizing the $P$. mirabilis chromosome. These are R772, a P-1 group plasmid (Coetzee, 1978 b, and unpublished), plasmid R394 belonging to the T incompatibility group (Coetzee, 1979) and the four plasmids described here, representing three other incompatibility groups. The pattern of chromosome mobilization of plasmids R394, R769 and R772 suggests that recombinants are produced in approximately equal numbers for markers situated in several different regions of the chromosome, whereas the remaining plasmids preferentially mobilize given regions of the chromosome producing 
polarized transfer of chromosomal markers. While many plasmids of various groups can transfer the E. coli chromosome (see, for instance, Moody \& Hayes, 1972; Hedén \& Rutberg, 1976; Hedén \& Meynell, 1976), this is a generous spread in comparison with organisms like A. calcoaceticus (Towner \& Vivian, 1977) and Rhizobium spp. (Beringer \& Hopwood, 1976; Kondorosi et al., 1977; Meade \& Signer, 1977; Beringer et al., 1978) where only certain P-1 incompatibility group plasmids have been reported to be capable of transferring the chromosome. In Pseudomonas spp., only group P-1 and P-2 plasmids (Shahrabadi et al., 1975) have been reported to be capable of chromosome mobilization (Haas \& Holloway, 1976; Lacy \& Leary, 1976). However, failure to transmit plasmids of many incompatibility groups to Pseudomonas spp. or A. calcoaceticus has prevented their study (Shahrabadi et al., 1975; Jacoby, 1974; Towner \& Vivian, 1977) in these organisms.

Plasmid D transfers between strains of Proteus at frequencies approaching $10^{-1}$ per donor (Coetzee, 1974) and mobilizes the proximal chromosomal marker (his-1) at a frequency of $2 \times 10^{-4}$ under optimal conditions (Coetzee, 1978 a). The latter figure divided by the former yields a ratio of $2 \times 10^{-3}$ which may be taken as a measure of the efficiency of chromosome transfer. The chromosome mobilizing efficiencies of $\mathbf{R}$ plasmids calculated from transfer data presented in the literature reveal that many have efficiencies similar to the calculated value for plasmid D. These include R68.45 in $R$. meliloti (Kondorosi et al., 1977), R68.45 and R9165 in Pseudomonas aeruginosa (Haas \& Holloway, 1976; Stanisich \& Holloway, 1971) and R1drd 19 in E. coli (Cooke \& Meynell, 1969). Plasmid RP4 in R. meliloti (Meade \& Signer, 1977) has a chromosome mobilizing efficiency of $10^{-4}$ and Hedén \& Rutberg (1976) described R plasmids R911 and R19011 with chromosome mobilizing efficiencies of $2 \times 10^{-2}$. The efficiency calculated from the frequency of plasmid transfer and transfer of chromosome markers by $\mathrm{R} 769$ is about $10^{-3}$. Similar calculations for proximal marker transfer by the other three plasmids tested give values of about $10^{-2}$ for all of them. The remarkably high efficiencies registered by these three plasmids for proximal marker transfer raise the question of the role that Hfr-like or $\mathbf{F}^{\prime}$-like $\left(\mathbf{R}^{\prime}\right)$ donors could play in this chromosome mobilization. The former possibility is unlikely as all recombinants had received a functional $\mathbf{R}$ plasmid (see Pearce \& Meynell, 1968; Beringer et al., 1978), while a decision has not been reached about the latter. Certainly the objection raised against the role that Hfr-like donors might play does not apply to R-primes (Pearce \& Meynell, 1968; Dixon et al., 1975; Johnston et al., 1978). Also the fact that the efficiency of chromosome marker mobilization does not approach unity (Johnston et al., 1978; Holloway, 1978) is not necessarily inconsistent with such a role. This is because efficiency varies with the combination of chromosome and R-prime involved and also R-primes may only represent a portion of the donor population. However, the donor properties of recombinants have not been studied (see Johnston et al., 1978; Holloway, 1978).

Plasmid R769 appears to mobilize slightly shorter portions of the $P$. mirabilis chromosome than plasmid R772 (Coetzee, 1978b) and much shorter than the lengths mobilized by plasmid R394 (Coetzee, 1979).

With the aid of plasmids R40a, Rip69 and R447b, which mobilize the P. mirabilis chromosome from three distinct origins in a clockwise direction, it has now been possible to complement the plasmid D-promoted gradient of transfer of the chromosome (anticlockwise) to prove chromosome circularity directly (Fig. 2). Previously (Coetzee, 1979) this had been done indirectly by means of linkage data. Uncertainty exists regarding intervals of time in the nalA region. This is due to the low recovery frequencies of donor markers encountered in this area (Fig. 1a). The latter could have resulted from the presumed dominance of the wild-type allele which would render merozygotes sensitive to the nalidixic acid used to inhibit chromosome transfer. Dominance has been proved for the wild-type E. coli gene (Hane \& Wood, 1969) and the same apparently applies to al $^{+}$loci in Pseudomonas aeruginosa (Watson \& Holloway, 1978). Physical disruption of the mating process in liquid medium is not feasible as transfer frequencies of chromosome markers under these condi- 
tions are too low (Coetzee, 1978a, and unpublished), and other means of disrupting chromosome transfer in mating on solid medium have not yet been attempted.

The author is in receipt of grants from the South African Medical Research Council.

\section{REFERENCES}

Beringer, J. E. \& Hopwood, D. A. (1976). Chromosomal recombination and mapping in Rhizobium leguminosarum. Nature, London 264, 291-293.

Beringer, J. E., Hoggan, S. A. \& Johnston, A. W. B. (1978). Linkage mapping in Rhizobium leguminosarum by means of $\mathbf{R}$ plasmid-mediated recombination. Journal of General Microbiology 104, 201-207.

Clowes, R. C. \& HAYes, W. (1968). Experiments in Microbial Genetics. Oxford and Edinburgh: Blackwell Scientific Publications.

Coetzee, J. N. (1974). Properties of Proteus and Providence strains harbouring recombinant plasmids between P-lac R1drd19 or R447b. Journal of General Microbiology 80, 119-130.

CoEtzeE, J. N. (1975). Chromosome transfer in Proteus mirabilis mediated by a hybrid plasmid. Journal of General Microbiology 86, 133-146.

Coetzee, J. N. (1978a). Extension of a chromosome linkage group of Proteus mirabilis. Journal of General Microbiology 107, 155-163.

Coetzee, J. N. (1978 b). Mobilization of the Proteus mirabilis chromosome by R plasmid R772. Journal of General Microbiology 108, 103-109.

Coetzee, J. N. (1979). Genetic circularity of the Proteus mirabilis linkage map. Journal of General Microbiology 110, 171-176.

Coetzee, J. N. \& Smit, J. A. (1970). Properties of Proteus mirabilis phage 13vir. Journal of General Virology 9, 247-249.

Coetzee, J. N., Datta, N., Hedges, R. W. \& Appelbaum, P. C. (1973). Transduction of $\mathbf{R}$ factors in Proteus mirabilis and $\boldsymbol{P}$. rettgeri. Journal of General Microbiology 76, 355-368.

Cooke, M. \& Meynell, E. (1969). Chromosomal transfer mediated by de-repressed $\mathrm{R}$ factors in $\mathrm{F}^{-}$ Escherichia coli K12. Genetical Research 14, 79-87.

Datta, N. \& Hedges, R. W. (1972). R factors identified in Paris, some conferring gentamicin resistance, constitute a new compatibility group. Annales de l'Institut Pasteur 123, 849-852.

Dixon, R., Cannon, F. C. \& Postgate, J. R. (1975). Properties of the $\mathbf{R}$ factor R144drd 3 in Klebsiella pneumoniae. Genetical Research 28, 327-338.

HaAs, D. \& Holloway, B. W. (1976). R factor variants with enhanced sex factor activity in Pseudomonas aeruginosa. Molecular and General Genetics 144, 243-251.

HANE, M. W. \& Wood, T. H. (1969). Escherichia coli $\mathrm{K}-12$ mutants resistant to nalidixic acid: genetic mapping and dominance studies. Journal of Bacteriology 99, 238-241.

Hedén, L.-O. \& MeYNell, E. (1976). Comparative study of R1-specific chromosomal transfer in Escherichia coli K-12 and Salmonella typhimurium LT2. Journal of Bacteriology 127, 51-58.

Hedén, L.-O. \& RUTBERG, L. (1976). R factormediated polarized chromosomal transfer in
Escherichia coli C. Journal of Bacteriology 127, 46-50.

Hedges, R. W. (1975). R factors from Proteus mirabilis and $P$. vulgaris. Journal of General Microbiology 87, 301-311.

Hedges, R. W. \& Datta, N. (1972). R124, an $f i^{+}$R factor of a new compatibility class. Journal of General Microbiology 71, 403-405.

Hedges, R. W., Datta, N., Coetzee, J. N. \& Dennison, S. (1973). $\mathbf{R}$ factors from Proteus morganii. Journal of General Microbiology 77, 249-259.

Holloway, B. W. (1978). Isolation and characterization of an $\mathbf{R}^{\prime}$ plasmid in Pseudomonas aeruginosa. Journal of Bacteriology 133, 1078-1082.

JACOBY, G. A. (1974). Properties of R plasmids determining gentamicin resistance by acetylation in Pseudomonas aeruginosa. Antimicrobial Agents and Chemotherapy 6, 239-252.

Johnston, A. W. B., Setchell, S. M. \& Beringer, J. E. (1978). Interspecific crosses between Rhizobium leguminosarum and $R$. meliloti: formation of haploid recombinants and of R-primes. Journal of General Microbiology 104, 209-218.

Kondorosi, A., Kiss, G. B., Forrai, T., Vincze, E. \& Banfalvi, Z. (1977). Circular linkage map of Rhizobium meliloti chromosome. Nature, London 268, 525-527.

LACY, G. H. \& LeARY, J. V. (1976). Plasmidmediated transmission of chromosomal genes in Pseudomonas glycinea. Genetical Research 27, 363-368.

Meade, H. M. \& Signer, E. R. (1977). Genetic mapping of Rhizobium meliloti. Proceedings of the National Academy of Sciences of the United States of America 74, 2076-2078.

MeYNELl, E. \& CoOKe, M. (1969). Repressor-minus and operator-constitutive de-repressed mutants of F-like $\mathbf{R}$ factors: their effect on chromosomal transfer by HfrC. Genetical Research 14, 309-313.

Meynell, E. \& DatTA, N. (1966). The relation of resistance transfer factors to the $\mathrm{F}$-factor (sexfactor) of Escherichia coli K12. Genetical Research 7, 134-140.

Meynell, E. \& Datta, N. (1967). Mutant drug resistant factors of high transmissibility. Nature, London 214, 885-887.

Moody, E. E. M. \& Hayes, W. (1972). Chromosome transfer by autonomous transmissible plasmids: the role of the bacterial recombination (rec) system. Journal of Bacteriology 111, 80-85.

MoODY, E. E. M. \& RuNGE, R. (1972). The integration of autonomous transmissible plasmids into the chromosome of Escherichia coli K12. Genetical Research 19, 181-186.

Ozeki, H., Howarth, S. \& Clowes, R. C. (1961). Colicine factors as fertility factors in bacteria. Nature, London 190, 986-989.

Pearce, L. E. \& Meynell, E. (1968), Specific 
chromosomal affinity of a resistance factor. Journal of General Microbiology 50, 159-172.

Shahrabadi, M. S., PrYAN, L. E., \& VAN DEN Elzen, H. M. (1975). Further properties of P-2 R-factors of Pseudomonas aeruginosa and their relationship to other plasmid groups. Canadian Journal of Microbiology 21, 592-605.

Stanisich, V.A. \& Holloway, B. W. (1971). Chromosome transfer in Pseudomonas aeruginosa mediated by $\mathbf{R}$ factors. Genetical Research 17, 169-172.

Sugino, Y. \& Hirota, Y. (1962). Conjugal fertility associated with resistance factor $\mathbf{R}$ in Escherichia coli. Journal of Bacteriology 84, 902-910.
Towner, K. J. \& Vivian, A. (1976a). RP4 fertility variants in Acinetobacter calcoaceticus. Genetical Research 28, 301-306.

Towner, K. J. \& Vivian, A. (1976b). RP4-mediated conjugation in Acinetobacter calcoaceticus. Journal of General Microbiology 93, 355-360.

Towner, K. J. \& Vivian, A. (1977). Plasmids capable of transfer and chromosome mobilization in Acinetobacter calcoaceticus. Journal of General Microbiology 102, 167-171.

Watson, J. M. \& Holloway, B. W. (1978). Chromosome mapping in Pseudomonas aeruginosa PAT. Journal of Bacteriology 133, 1113-1125. 